\title{
COMENTARIO
}

\section{Manuel Cortés Barrientos}

Abogado-Profesor de Derecho Civil

Universidad Católica del Norte (Sede Coquimbo)

Las dos primeras sentencias que se han transcrito representan la actividad jurisdiccional de jueces árbitros, que actúan al alero del Centro de Arbitrajes y Mediación de la Cámara de Comercio de Santiago, que desde hace varios años cumple con acierto, prestancia, celeridad y alcurnia jurídica, dicha tarea de tribunal de compromiso.

Es un buen ejemplo de la tarea del arbitraje al servicio de la comunidad, donde la primera instancia estuvo representada por un ex Ministro de la Excma Corte Suprema, y la segunda por los Decanos de las Facultades de Derecho de las universidades más tradicionales del país, y de una del ámbito privado, dos de ellos son además abogados integrantes del más alto tribunal.

Resulta a este respecto, trascendente detenerse en la labor de la justicia arbitral, cuya tarea futura, ampliada y mayor, depende de un proyecto de ley en actual tramitación legislativa $y$, que ha sido impulsado prioritariamente por el Instituto Chileno de Derecho Procesal.

En seguida, pone al tapete del análisis jurídico y de la observación de los abogados, la necesaria e indispensable revisión de los antecedentes de una persona jurídica, cuando contrata.

No se trata simplemente de leer los artículos pertinentes del Código Civil que regulan a estas personas jurídicas, nacidas prácticamente como incapaces relativas en la legislación original de nuestra codificación en cuanto al pleno ejercicio de us derechos, sino que asimismo de analizar los reglamentos de la ley, sus estatutos y reglamentos en cuanto modificatorios o restrictivos de su quehacer en el mundo del derecho.

El exhaustivo análisis que efectúa el SJA don Adolfo Bañados, es una clase descriptiva de los elementos de interpretación que han de buscarse para dar adecuada aplicación a una norma, pero a su vez son una adecuada demostración de lo que ha de hacer un estudioso del derecho, para establecer la titularidad de una representación por parte de personas naturales relativa a la persona jurídica. 
La norma no sólo se ha buscado en su elemento gramatical y su sentido literal, sino que también ha visto la normativa similar en el derecho positivo nacional, con abundancia de cita de decretos reglamentarios, a la vez que con acopio de información doctrinaria no solo nacional sino que también extranjera, todas ellas coincidentes hacia el derrotero razonado por el sentenciador.

Los distintos órganos de la generación de la voluntad en la persona ficta, asamblea, el directorio y el presidente-, desempeñan roles diversos que, han de ser analizados en cada caso particular con la ley, los estatutos, y los reglamentos particulares, los cuales sin contradecir las facultades expresas del texto legal, pueden restringir o exigir voluntades complementarias o actos de ratificación respecto de los actos de los mandatarios.

El análisis de los bienes incorporales en cuanto objeto del contrato sub lite, las descripciones de aquello que fue lo contratado y su armónico significado acorde lo establecido en su propio estatuto por la demandada, fueron también estudiadas en el fallo y globalizan en la sentencia las ideas del juzgador, para concluir en el rechazo de la demanda.

En suma tal fallo de primera instancia es una exposición vasta de los requisitos exigidos a la persona jurídica -corporación- para verificar la calidad de sus representantes y cómo y de qué forma obligan a su representada.

Y a la vez, el fallo de la Excma Corte Suprema en el recuso de casación en el fondo, centra con claridad meridiana la procedencia de la interposiciòn del mismo, respecto de infracciones que no son de ley, estableciendo una vez más, el concepto de ley para los efectos de la interposición del recurso de casación en el fondo.

El fallo comentado tiene numerosas y trascendentes materias que analiza en su texto y permiten compartir con el sentenciador, la justeza de su raciocinio y conclusión, a la vez que ilustrar al lector de temas jurídicos sobre tales materias, 